(Jurnal Teknologi Komputer dan Sistem Informasi)

Februari 2021, Vol 1, No 1, Hlm. 34-39

Available online at http://jurnal.goretanpena.com/index.php/teknisi

\title{
DISPLAY DATA KEYBOARD PERSONAL KOMPUTER PADA DOT MATRIKS
}

\author{
${ }^{1}$ Benny Agus Simanungkalit, ${ }^{2}$ Fictor pakpahan \\ ${ }^{1,2}$ Fakultas Teknik/Prodi Teknik Elektro Universitas Efarina \\ Email:Benny.agus@gmail.com
}

\begin{abstract}
Abstrak :Sistim pemrograman mikrokontroler pada running text yang biasa dilakukan untuk mengganti tulisan informasi yang akan ditampilkan pada umumnya dilakukan dengan cara mendownload dengan komputer. Pemrograman penampilan informasi yang dilakukan dengan cara mendownload dengan komputer belum efesien, karena harus membutuhkan komputer dan downloader. Ic AT89S52 dapat membaca data kode scan keyboard komputer dan memprosesnya untuk diteruskan ke display running text. Display running text disusun dari LED secara dot matriks. Penggerak display running text model dot matriks dibuat ic 4094. Ic 4094 melakukan penerimaan data secara serial dan mengirimkannya secara paralel maupun serial. Alat yang dirancang penulis telah dapat menampilkan karakter huruf, angka, dan tanda baca sesuai dengan kode scan yang dikirimkan keyboard komputer.
\end{abstract}

Kata Kunci : Display, Matriks, Keyboard, Komputer, Mikrokontroller.

\section{PENDAHULUAN}

Perkembangan

teknologi

mikrokontroler telah membawa era baru dalam dunia elektronika. Salah satu bentuk penerapannya sebagai pengendali karakter,dimana alat ini berfungsi untuk menampilkan suatu informasi berupa huruf, angka, dan tanda baca yang berasal dari keyboard dan menggunakan lampu LED sebagai display.

Dalam perancangan alat ini, menggunakan mikrokontroler AT89S52 sebagai pengolah data sekaligus penerima data keyboard dan menyimpan data-data biner yang diterima untuk mengendalikan dot matriks LED sebagai output data.

Ada empat jalur yang menghubungkan keyboard dan PC. Dua dari konektor adalah power supply dan ground, yang digunakan untuk memberikan tegangan ke rangkaian keyboard. Dua sinyal yang lain adalah sebagai berikut:

1. Data keyboard : Disinilah jalur bitbit data dan perintah yang akan dikirimkan ke sistem PC dari keyboard.

2. Clock keyboard : Ini merupakan sinyal clock regular, dengan suatu nilai yang berosilasi dari logika "1" ke " 0 " dengan pola yang teratur. Tujuan dari sinyal clock ini adalah untuk mesinkronisasikan keyboard dan sistem, sehingga mereka selalu bekerja secara bersamaan.

Keyboard PC AT yang terkoneksi, hanya menggunakan empat buah kabel, kabel ini ditunjukkan pada gambar 2.2 menunjukkan konfigurasi pin-pin serial keyboard dan fungsinya, untuk 5 pin DIM dan 6 pin(PS/2)

Transmisi data, dari keyboard ke siste, dilakukan dengan frame 11 bit. Bit pertama adalah bit start ( logika 0 ), diikuti dengan 8 bit data ( LSB first), satau bit paristas ( paritas ganjil ) dan bit stop ( logika 1 ). Setiap bit harus dibaca pada sisi turun dari clock 


\section{(Jurnal Teknologi Komputer dan Sistem Informasi)}

Februari 2021, Vol 1, No 1, Hlm. 34-39

Available online at http://jurnal.goretanpena.com/index.php/teknisi

\section{METODE}

Rancangan ini terbagi tiga bagian, yakni : sistem minimum mikrokontroler AT89S52, catu daya dan display yang terdiri dari LED matriks 7X16. Ketiga bagian ini terpisah satu sama lain yang hanya dihubungkan dengan menggunakan kabel. Adapun blok diagram dispaly ini sperti pada gambar 1 .
Berfungsi untuk menampilkan karakter huruf, angka dan tanda baca yang menjadi suatu tulisan

4. Keyboard.

Berfungsi sebagai sumber data yang berupa karakter huruf, angka, dan tanda baca yang berbentuk data-data biner yang dikirimkan secara serial.

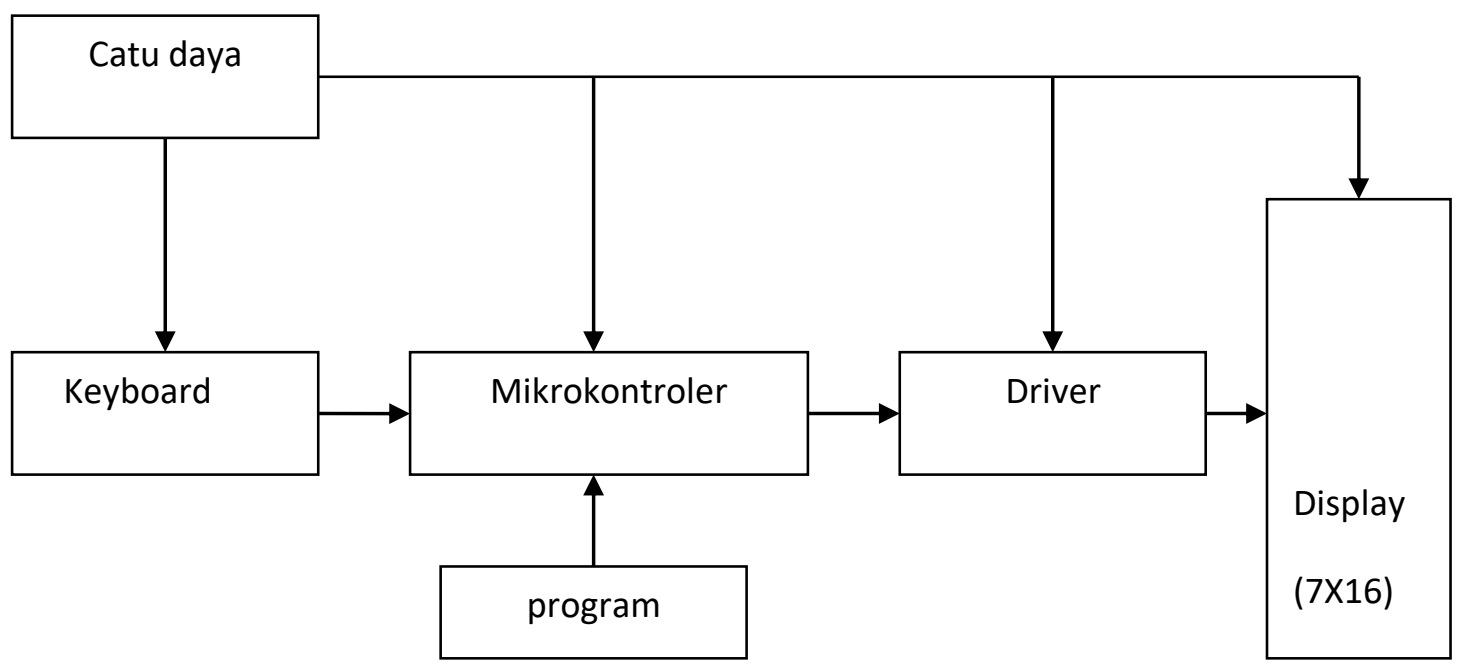

Gambar 1 Diagram dispaly data keyboard

Fungsi masing-masing blok :

1. Mikrokontroler.

Berfungsi sebagai pengolah data yang dikirim pada display sekaligus menyimpan data tersebut dalam flash PEROM mikrokontroler AT89S52.

2. IC HEF 4094.

Adalah register serial to paralel yang berfungsi untuk mengubah data seri dari mikrokontroler AT89S52 menjadi data paralel dan Perancangan Sistem Minimum Mikrokontroler AT89S52 Mikrokontroler AT89S52 mempunyai port serial untuk komunikasi data serial secara full-duflex, sehingga memungkinkan kita untuk memanfaatkan port ini berhubungan dengan interfice yang dalam hal ini adalah IC HEF 4094. Adapun rangkaian sistem minimum mikrokontroler untuk runing text dapat dilihat pada gambar 2 . menggeser data tersebut pada baris berikutnya, untuk menghidupkan dan mematikan lampu LED pada baris dan kolom sesuai dengan data yang dikirim oleh mokrokontroler.

3. LED yang disusun secara Matriks 


\section{(Jurnal Teknologi Komputer dan Sistem Informasi)}

Februari 2021, Vol 1, No 1, Hlm. 34-39

Available online at http://jurnal.goretanpena.com/index.php/teknisi

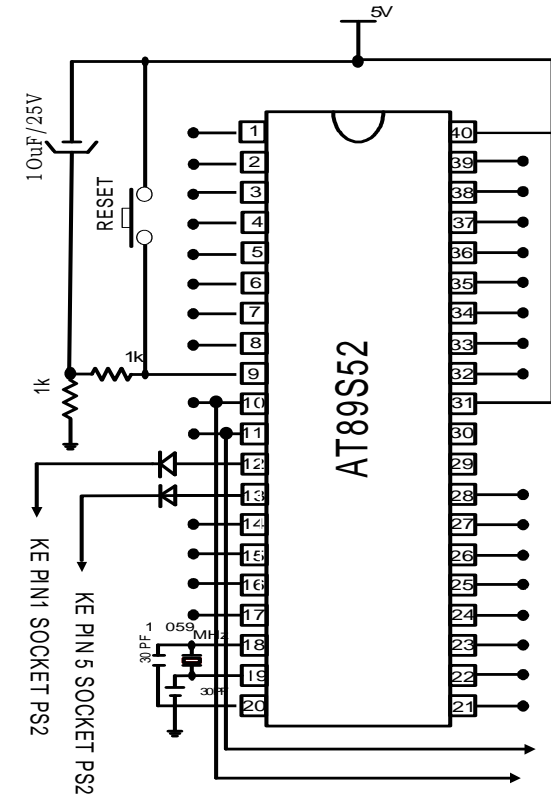

Gambar 2 Rangkaian Minimum Mikrokontroler AT89S52.

Perancangan Display Dot MatriksLED matriks merupakan kumpulan sumber/titik cahaya LED yang tersusun sejumlah kolom dan baris. LED matriks yang digunakan dalam tugas akhir ini tersusun menjadi 7 baris x 16 kolom LED, jadi dalam displaynya memerlukan 112 buah LED. Ke 112 LED tersebut dapat menghasilkan maksimum 3 karakter (huruf) sekali tampil pada display. Rangkaian LED matriks, pada gambar 3 .

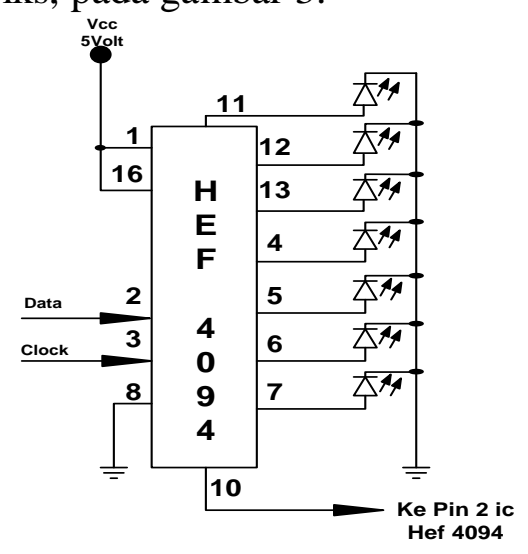

Gambar 3 Display data

Pada gambar diatas dapat kita lihat bahwa untuk membentuk satu kolom display, memerlukan satu buah IC HEF 4094, sehingga untuk menghasilkan 3 karakter pada display dibutuhkan 16 buah IC.

Untuk memperagakan karakter dalam LED matriks yang diperlukan tidak dinyalakan secara serentak, akan tetapi LED ini diaktifkan baris demi baris dengan cepat sesuai dengan instruksi yang tersimpan dalam Flash PEROM mikrokontroler AT89S52.

\section{Perancangan Pemanfaatan Keyboard}

Rangkaian keyboard yang disertakan pada alat ini berfungsi sebagai sumber KE PIN3 IC HEinpat data yang akan disambungkan ke KE PIN2 IC HEFAOP4 mikrokontroler AT89S52. Penggunaan keyboard pada perancangan berbasis mikrokontroler adalah untuk mengontrol jalannya alat yang dirancang. Keyboard akan menberikan data-data biner berupa karakter huruf, angka, dan tanda baca yang dikirimkan secara serial.Data atau karakter yang dikirimkan keyboard saat ditekan akan mengarahkdn ke garis alamat bersama. Data akan terkirim sesuai dengan peralihan waktu yang maksimal(CP).

Bentuk perancangan keyboard pada alat yang dirancang ditunjukkan pada gambar 4.

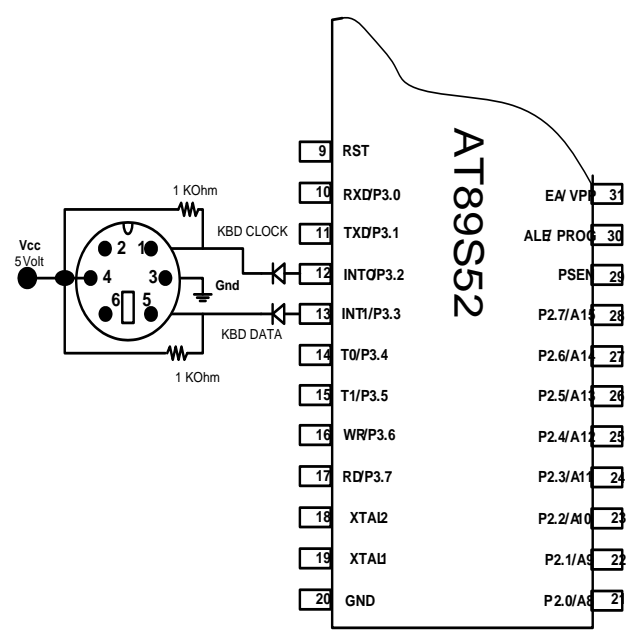

Gambar 4 rangkaian Keyboard

Komputer PS/2 


\section{(Jurnal Teknologi Komputer dan Sistem Informasi)}

Februari 2021, Vol 1, No 1, Hlm. 34-39

Available online at http://jurnal.goretanpena.com/index.php/teknisi

Perangkat Lunak (software)

Perancangan dan pembuatan perangkatan lunak dilakukan untuk mengendalikan perangkat keras yang telah di buat. Perancangan dan pembuatan perangkat lunak harus disesuaikan dengan perangkat keras, hal ini dimaksudkan agar perangkat lunak dan perangkat keras bisa kompatibel.

Sebelum membuat perangkat lunak terlebih dahulu kita membuat diagram alir (Flow Chart). Diagram alir ini menggambarkan urutan pembuatan program, dengan demikian urutan program yang kita buat lebih terarah.

Diagram Alir (Flow Chart)

Diagram alir program pada runing text berbasis mikrokontroler AT89S52 seperti ditujukkan pada gambar 5.

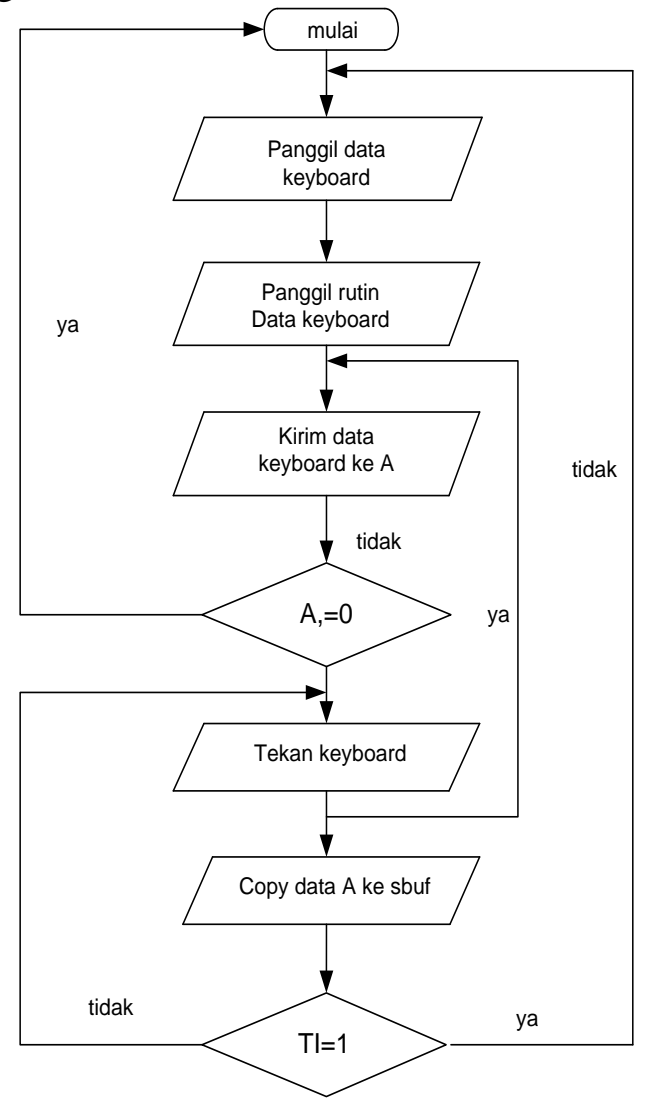

Gambar 5. Flow Chart
HASIL DAN PEMBAHASAN

Data karakter keybaord

Setiap karakter yang akan ditampilkan pada display adalah tulisan berjalan dari kanan ke kiri. Untuk menampilkan sebuah huruf pada display, maka kolomkolom tempat tampilnya huruf tersebut harus dihidupkan secara bergantian dalam waktu yang cepat, sehingga tampak bahwa sepertinya kolom-kolom tersebut hidup secara bersamaan. Gambar 3.6 menunjukkan cara pembentukan karakter "A".

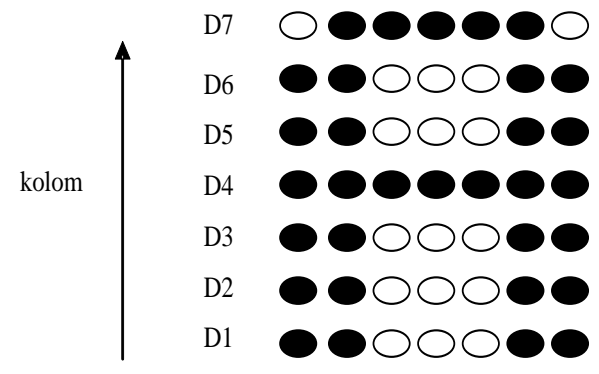

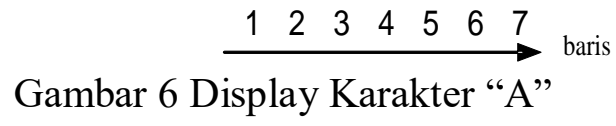

Pada gambar 6, bentuk karakter " $A$ " yang telah ada diubah menjadi data-data biner dengan cara memberi nilai 1 pada led yang hidup dan memberi nilai 0 pada led yang mati. Urutan pemberian nilai logika, mulai dari nomor satu hingga nomor tujuh. Data karakter "A" tersebut seperti terlihat pada tabel 1 .

Tabel 1 Data Display

\begin{tabular}{|c|c|c|c|c|c|c|c|}
\hline \multirow{2}{*}{ Kolom } & 1 & 2 & 3 & 4 & 5 & 6 & 7 \\
\cline { 2 - 8 } & D0..D7 & D0...D7 & D0..D7 & D0..D7 & D0..D7 & D0...D7 & D0...D7 \\
\hline Data Biner & 0111 & 0111 & 0000 & 0000 & 0000 & 0111 & 0111 \\
1110 & 1111 & 1001 & 1001 & 1001 & 1111 & 1110 \\
\hline $\begin{array}{c}\text { Data Heksa- } \\
\text { Desimal }\end{array}$ & $7 \mathrm{EH}$ & $7 \mathrm{FH}$ & $09 \mathrm{H}$ & $09 \mathrm{H}$ & $09 \mathrm{H}$ & $7 \mathrm{FH}$ & $7 \mathrm{EH}$ \\
\hline
\end{tabular}

Jadi untuk membentuk sebuah karakter "A" , maka data yang harus diberikan adalah 7eH, 7FH, 09H, 09H, 09H, 7F dan 7EH. Data yang sudah ada ini kemudian diisikan kedalam register 


\section{(Jurnal Teknologi Komputer dan Sistem Informasi)}

Februari 2021, Vol 1, No 1, Hlm. 34-39

Available online at http://jurnal.goretanpena.com/index.php/teknisi

serial buffer (SBUF) mikrokontroler AT89S52.

\section{Pengujian Program assembly}

Setelah file dibuat dan disimpan, pilih menu Assembly yang ada pada editor 8051 IDE. Diperhatikan apakah data ada yang error atau tidak, jika ada data yang error,maka diperbaiki data yang error hingga hasilnya tidak error lagi.

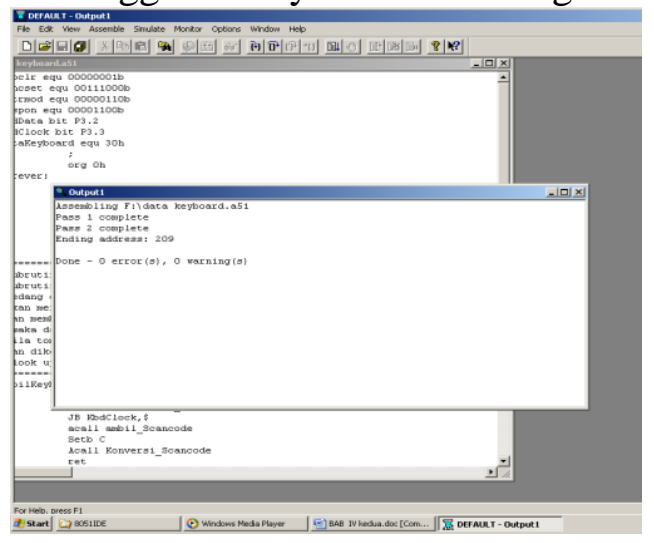

Gambar 7 Tampilan setelah di Assemblykan

Selanjutnya direload file untuk mendownload program kedalam chip mikrokontroler .

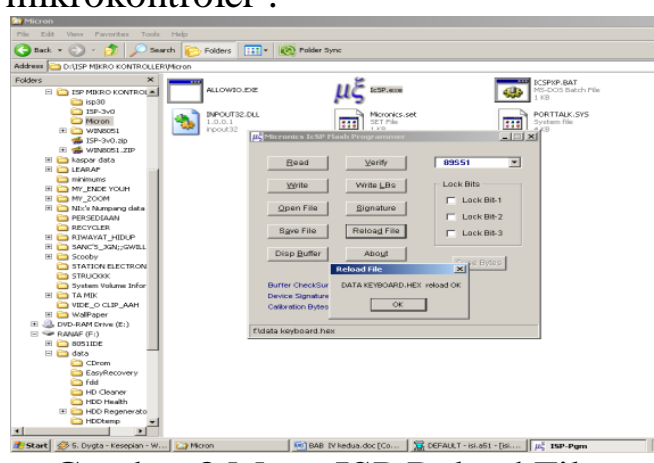

Gambar 8 Menu ISP Reload File

Matikan catu daya downloader dan chip mikrokontroler dapat dipindahkan pada minimum sistimn setelah itu ikuti langkah berikut;

1. Setelah selesai didownload dilakukan pengujian chip AT89S51 pada rangkaian minimum sistim.
2. Dihidupkan catu daya pada rangkaian minimun sistim, dan rangkaian pengerak hef4094, dan LED.

3. Dihubungkan konektor keyboard ke rangkaian minimum sistim.

4. untuk melakukan penggantian tampilan yang akan ditampilkan pada display tekan reset, kemudian ketik tulisan yang mau ditampilkan.

5. Maka dari hasil pengujian ini dapat menampilkan tulisan berjalan (running text) sesuai apa yang akan kita ketik dari keyboard misalnya: "ABCDEFGHIJKLMNOPQRSTUV WXYZ".

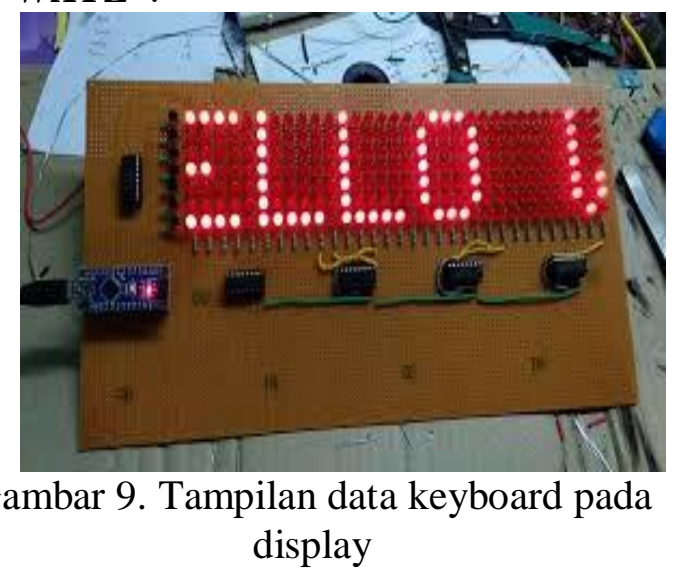

\section{Analisis Pembahasan}

Setelah diajukan uji coba terhadap alat dirancang telah berfungsi sebagaimanb yang ditentukan pada software daan hardware. Bentuk karakter yang ditampilkan sesuai dengan konversi kondisi lampu hidup(1) dan mati(0) secara biner. Urutan letak sambungan LED ke keluaran ic 40494 sangat menentukan dalam pembuatan software dan pengurutan outputic 4094, penulis buat seperti O0, O1, O2, O3, O4, O5, O6, dan O7. ada juga urutan model keluaran dibuat seperti ini $\mathrm{O} 2, \mathrm{O} 3, \mathrm{O} 1$, O0, O4, O5, O6, dan O7. kondisi lampu led hidup dan mati telah dibuat secara biner, selanjutnya dikonversikan ke heksadesimal. 


\section{(Jurnal Teknologi Komputer dan Sistem Informasi)}

Februari 2021, Vol 1, No 1, Hlm. 34-39

Available online at http://jurnal.goretanpena.com/index.php/teknisi

\section{KESIMPULAN}

Setelah menyelesaikan penelitian ini, maka ditarik suatu kesimpulan antara lain:

1. Dengan memanfaatkan keyboard, maka penggantian tulisan informasi pada display LED Matriks secara langsung dengan keyboard dapat diwujudkan.

2. Untuk membuat satu karaktere huruf, angka, dan tanda baca dibutuhkan led sesuai dengan bentuk karakter yang akan ditampilkan.

3. Setiap tombol pada keyboard dapat digunakan untuk mengendalikan tulisan informasi yang akan ditampilkan kedisplay

\section{DAFTAR PUSTAKA}

[1] Sri Widodo Thomas, Dr.Ir.2002. Elektronika Dasar. Jakarta: Erlangga

[2] Utomo, Suprapto, Rahmatul Irfan, 2008, Teknik Telekomunikasi Jilid 2, Jakarta : Direktorat Pembinaan Sekolah Menengah Kejuruan, Direktorat Jenderal Manajemen Pendidikan Dasar dan Menengah, Departemen Pendidikan Nasional,
[3] Wasito S., 1986, Vademekum Elektronika, cet. ketiga, Jakarta: PT Gramedia

[4] Robert Boylestad and Louis Nashelsky, 1994, Electronic Devices And Circuit Theory: India Private Ltd, New Delhi

[5] Anton F. P. van Putten, 1988, Electronic Measurement Systems, Prentice Hall International (UK) Ltd.

[6] Nalwan Andi Paulus. 2003. Teknik Antarmuka dan Pemrograman mikrokontroler AT89C51. Jakarta : PT Gramedia

[7] Astrawan Putra, Putu Yudi. Perancangan dan Pembuatan Simulasi Pembangkit Listrik Tenaga Surya (PLTS). Universitas Pendidikan Ganesha. Singaraja. 2007.

[8] Maters, Gilbert M. Renewable and Efficient Electric

[9] Power System. A John Wiley \& Sons. Inc. 2004.

[10]Yakin and E. A. Z, "Perencanaan Pembangkit Listrik Hybrid Di Pulau Gili Labak Kabupaten Sumenep Madura Menggunakan Teknik Distributed Generation," Semin. Nas. Sains dan Teknol. Terap. IV, pp. 265-272, 2016. 